\title{
Indigenous "People" in the context of the Right to Self Determination: A Critical Appraisal
}

\author{
Mitul Dutta ${ }^{1} \&$ Navin Sinha ${ }^{2}$ \\ ${ }^{1}$ Asst. Professor, School of Law, KIIT University, KIIT University, Bhubaneshwar, Orisha. \\ ORCID id- https://orcid.org/0000-0002-6800-8469. Email: mituldutta@kls.ac.in. \\ ${ }^{2}$ Asst. Professor, School of Business and Law, Navrachna University, Navrachna University, \\ Vadodara, Gujarat. ORCID id- https://orcid.org/0000-0003-3086-3504 \\ Email: navins@nuv.ac.in.
}

\begin{abstract}
Under the international human rights regime, the right to self-determination is a right guaranteed to the groups of "people". This right is one of the most controversial issues of international law as it comes into conflict with the principle of sovereignty and territorial integrity of the states. There are various uncertainties associated with this right regarding the scope of the right and mode of implementation etc. The present article seeks to make an in-depth analysis of the claimants of the right and the uncertainties associated with the meaning of the term "people" in the context of the right to self-determination. The article encompasses, among other things, the right of indigenous people under various international instruments and how they interrelate to the right of self-determination.
\end{abstract}

Keywords: Right to self-determination, people, indigenous people.

\section{Introduction}

The right to self -determination is one of the most debated issues of international law. It is a right that cannot be exercised by an individual rather it is guaranteed to groups of 'people'. By virtue of this right, a group of people are enabled to determine their political status and pursue their economic and cultural development. The rationale behind this right is to enable the groups of "people" to flourish and preserve the distinctiveness of their culture, language, tradition, culture etc. The right exists in two forms namely, internal self-determination and external selfdetermination (Ali, 2014, p. 431). The internal Self-Determination can be exercised though claims of political autonomy and economic freedom within the constitutional framework of the parent state. On the other hand, external self- determination claims include claims of self-governance and independence from the parent state. In its widest sense, right to self-determination includes claims to form an independent sovereign state and secede from the patent state (Ali, 2014, p. 431). 
The term 'self-determination' was recognised Under the Charter of United Nations as a fundamental principle of the United Nations (UN, UN Charter, 1945). Subsequently, the two human rights instruments adopted by the UN namely the International Covenant on Civil and Political Rights and the International Covenant on Economic, Social and Cultural Right recognised self-determination as a human right (UN, ICCPR, 1966). It has also been endorsed by the UN General Assembly resolution Declaration on Granting of Independence to Colonial Countries and Peoples, 1960 (UN, Declaration on Granting of Independence to Colonial Countries and Peoples, 1960) ii and the general assembly adopted the Resolution on the Declaration on the Principles of International Law Concerning Friendly Relations and Cooperation among the States in Accordance with the Charter, 1970.

Despite the recognition the right in the two human rights instruments, the contours of the right to self-determination remains highly undefined and ambiguous. There are a number of issues that surrounds the right to self-determination and some of these issues are highly controversial even today. For example, it is often asked whether self-determination encompasses the right to secede? Or whether a secessionist entity can unilaterally declare its independence from the parent states? Moreover, there are also issues concerning the implementing the right to self- determination. One major issue that forms the core of the debate on self-determination is the status of the "people" who are entitled to claim it. So far the identity of the "peoples" remains an elusive component in all major international instruments, including international state practices.

The present article takes up for discussion the status of peoples in self-determination. It will analyse the meaning of peoples in the context of self-determination and how major international instruments and states have responded to it. It will also look into the question whether within a colonial context and whether the indigenous people residing within the sovereign states are entitled to self-determination (Anaya, 1996, p. 103). The article follows a doctrinal method of inquiry and makes a comparative study of relevant international instruments containing rights of indigenous people.

\section{Defining 'People' in the context of Self- Determination}

Despite being the driving force behind all major conceptualisation of self-determination, the concept of people by far has been the most difficult to define. It should be noted that within the context of colonial independence the emphasis was more on decolonisation and independence from colonial control. It could be argued therefore, that there was no need to create a conceptual idea of self-determination that revolved around the class or categories of people that were entitled to it. Outside the colonial context, however, as more and more groups are asserting their right to self-determination, the controversy on self-determination has shifted decisively on the definition of peoples.

Over the years several theories have been proposed to provide a conceptual clarification underlying the meaning of peoples entitled to self-determination. The theories (for most part) are built around the idea of political legitimacy, indicating, the category and class of people entitled to self-determination. To begin with the national self-determination theory, where "nationalism" 
is the basis of self-determination and 'proposes that the basis for legitimate authority is a nation or people' (Miller, 1998, p. 65). A nationalistic understanding of self-determination defines people in terms of their residence in a territory. According to Buchanan such people share what he refers to as ascriptive characteristics "that are ascribed to individuals independently of their choice" and include being of the same nation or being a "distinct people" (Buchanan, 2017). The claims of selfdetermination of such peoples flow from the fact that they belong to a nation that by itself is sufficient condition for unilateral secession.

Similarly, the plebiscitary theory draws it definition of "people" based on the will of the majority (residing in a part of the mother state) to have their own state to govern their own affairs. The plebiscitary theory also does not draw its definition of people from any distinct traits that the people share, their justification lies in the commonly shared will of the majority to have their own government (Philpott, 1995, p. 363). As argued by Brando and Galvez, the plebiscitary theory is also justified as being "founded upon the aggregate individual autonomy of each of its members" (Brando \& Morals-Galvez, 2019, p. 107). Drawing from the moral force of democracy as the right to choose a government of one's own choice they argue that "a plebiscite with a majority vote (or super-majority, or a referenda procedure) in favour of self-determination and/or secession should justify a group's right to govern its own affairs" (Brando \& Morals-Galvez, 2019, p. 107) Similarly Philpott also claims that "the good of the members' autonomy is alone sufficient to justify self-determination" (Philpott, 1995, p. 363) Accordingly, the plebiscitary theory sees people as any group of people whose commitment to avail their own system or form of governance entitles them to self-determination.

On the other hand, according to the Buchannan's 'Remedial Right Only' theory, the justification of secession rests on a definition of people whose claim to secession is available as a "last resort' against 'serious and persistent violations of basic rights" (Buchanan, 2017). It is important to note that even though Buchanan stresses on a criterion that does not rest on territorial attributes, its operational efficacy is partly depended on a pre-determined identification of peoples who are entitled to this right. While Buchannan do not make it clear whether a precondition of residence is conditional for invoking a remedial justification of secession, it seems he acknowledges the idea of a nationalistic bond between the people and their territory is inherently built up in his theory. Any contrasting claim would only lead to a situation wherein people, even without a pre-existing nationalistic identity can claim secession.

Thus, even though the concept of "peoples" in the context of self-determination is largely indeterminate, we can still narrow down the specific contexts in which the word people is applied in self-determination. Basically, speaking people in self-determination could refer to the colonial peoples, the peoples of states, people under foreign domination, minorities and indigenous people.

\section{Indigenous People Under International Law}

One of the most deploring consequence of colonisation has been the manner in which indigenous people have been treated by the colonial governments. Maureen Davis, for example, notes that "invasion of Indigenous territories [has] been characterized by an enduring holocaust of 
unparalleled proportions" (Davis, 1988, p. 45)." Similarly, Catherine Iorns, argues that indigenous people "have in common a history of conquest by another group and subordination within their present states" (Iorns, 1992, p. 151). According to Irons, the problems besotting these people goes beyond political suppression, and includes economic and cultural oppression as well (Iorns, 1992, p. 201). These problems, as Catherine argues are characterised by a loss of lands and cultural and ethnic identity. Catherine further, argues that most of these problems "stem from the basic attitude of non-indigenous peoples that indigenous ways of life are backward and inferior and not appropriate for a 'civilized' society" (Iorns, 1992, p. 308).

Unfortunately, international law contains no specific definition of indigenous people. There is, however, an indicative framework of indigenous people in state practices.iii In most cases indigenous people are referred to as groups, possessing distinct ethnic identities within respective states (16 GAOR (1961), 1961, p. 21). These communities are in turn are characterised by a "close attachment to the land, both in terms of their culture and identity and sustenance; and their engagement with traditional economic activities, which also underpin their culture (Barten, 2015, p. 177)." Indigenous people also refer to people who have lived on certain territory from time immemorial and "who have been pursuing their own concept of development and attempting to maintain their identity, languages, traditional customs, beliefs and values, their lifestyles and control over their lands and natural resources" (UN, Resource kit on Indigenous Poeples' Issues, 2008).

One important problem posed by the concept of indigenous people, even assuming that states agree to the concept is how it would relate to the right of self-determination. Many states have refused to use the term indigenous people and instead refers to such group as "indigenous population" (Summer, 2014, p. 317; Committee, 2009, p. 5; Council, 2006, p. 10; Committee on Economic, 2012). . This is done basically to deemphasise the word people's as it can give rise to assumptions that such groups constitute a unit of self-determination. As Summers observe the concern was essentially to "establish borders around the term" in order to "delineate and contain the rights that could be associated with the concept" (Summer, 2014, p. 317). To get over this impasse, the United State suggested interpreting indigenous groups as non-collective groups (Rights , p. 40; Summer, 2014, p. 319). A different interpretation suggested that indigenous people were distinct peoples outside the purview of peoples entitled to self-determination (Quane, 2011, p. 268). Therefore, even assuming that such people were entitled to self-determination, it was a different self-determination. This interpretation was later endorsed by the ILO Convention 169, which under Art 1(3) held that:

"the use of the term 'peoples' in this Convention shall not be construed as having any implications as regards the rights which may attach to the term under international law" (Quane, 2011, p. 268).

Several states have endorsed this interpretation of the term. Canada, for example, suggested that the word peoples - in the case of indigenous peoples - should not have any implications in international law specifically self-determination (RIGHTS, 1993, p. 19). Germany and Great Britain also suggested similar interpretations of the term peoples and argued that indigenous people were different from the peoples entitled to self-determination (Council H. R., 2006, p. 53; Assembly, 2007). 
It should be noted that the concept of indigenous people has not always been welcomed by some Asian countries. The argument is that the concept of indigenous people imposes colonial ideas on Asian and African countries since it cannot be said with certainty who lived first in the state in question (Kingsbury, "Indigenous Peoples" in International Law: A Constructivist Approach to the Asian Controversy, 2008, pp. 121-122; Kingsbury, Indigenous Peoples" in International Law: A Constructivist Approach to the Asian Controversy', 1998). Moreover, it is generally argued that most questions pertaining to indigenous persons are political in nature which can escalate similar demands among other groups. Thus, in Asia, there are many countries, like China, India, Bangladesh and Myanmar where indigenous people are not recognised. Commenting on this issue Agnieszka Szpak writes that the reluctance to recognise indigenous people flows from the "claim that all citizens are equally indigenous but this approach is an expression of the assimilationist attitudes of States" (Agnieszka Szpak, 2018, p. 161). The matter was also addressed in the reports of the UN Special Rapporteur on the Rights of Indigenous in 2013 (Anaya J. , 2012). He stated that he was aware that the "vast majority of the population in Asia could be considered indigenous" while also observing that given the discrimination that these people are subject to, it was time that these problems were recognised and steps be taken to implement their individual and collective rights (Anaya J. S., 1996). While defining indigenous people James Anaya focuses on the "preinvasion" inhabitation of these people in the concerned geographical region. Thus, he seeks to distinguish them from "settler society" which he observes were "born of the forces of empire and conquest" (Anaya J. , 2012, pp. 5-6).

Indigenous representatives have also objected to an objective definition of the group as they consider such definitions as exclusionary in nature (Summer, 2014, p. 317). The problem with defining indigenous people is that most reports on indigenous people comes only from a handful of places. For example, most of the reports on this issue comes from the Americas, the Scandinavian purpose, Russia, Ukraine and Nepal and Philippines to a certain extent (Summer, 2014, pp. 317-19). Interestingly, as Summers observed that in some cases states have created false nomenclatures like "small indigenous peoples", "indigenous nationalities", and "indigenous nations", to the UN Human Rights Committee in their reports (Summer, 2014, p. 319). Summers observe that the Human Rights Committee usually does not require the states to report groups in those terms (Summer, 2014, p. 267). Indeed, to avoid the use of the expression "indigenous people", states have at times categorise them under different groups altogether. They claim is that if they look like peoples as is normally understood under international law, then they are peoples all the same.

Summers however argue identifying an objective definition of indigenous population can have exclusionary implications (Summer, 2014, p. 317). In other words, this may lead to a situation in which the entire nation can identify themselves as indigenous. According to the ILO Convention 1969 indigenous people are regarded "as indigenous on account of their descent from the populations which inhabited the country, or a geographical region to which the country belongs, at the time of conquest or colonisation or the establishment of present state boundaries and who, irrespective of their legal status, retain some or all of their own social, economic, cultural and political institutions (ILO)." 
This conceptualisation of indigenous people was used by India, Pakistan and Indonesia to identify the whole population as indigenous (Assembly, A/61/PV.107, UN). In effect this completely negated the existence of indigenous people in their respective countries. As of now the UN Declarations on the Rights of the Indigenous People is the most significant legal instrument in the area of the self-determination of indigenous people. A significant aspect of this declaration of this Declaration is that it does not qualify the word people and indigenous peoples are treated as people under the Declaration. This interpretation follows from the reading of the Preamble in which indigenous people are treated at par with "all other peoples (United Nations Declaration on the Rights of Indigenous Peoples, 2007)".

The Declaration also reinforces the general idea that indigenous peoples "contribute to the diversity and richness of civilizations and cultures, which constitute the common heritage of humankind" (United Nations Declaration on the Rights of Indigenous Peoples, 2007, Art. 1). According to the Declarations the rights vested in the indigenous people are both individual and collective in nature (Barten, 2015, p. 151). They have individual rights as members of the group while the collective rights are vested in the group as a whole (Barten, 2015, p. 151). Several other articles refer to several other rights. For example, Art 3 refers to the right to self-determination of the indigenous people. Art 4 refers to autonomy and self- governance in the exercise of the right to self-governance. Art 4 emphasises on matters relating to internal and local affairs of the indigenous people thus allowing a possible scope for internal self-determination.

Even as regards the right to self-determination of the indigenous people the emphasis is on the territorial integrity of the state to which they belong. This idea is reinforced under Art 46 of the Declaration which states that,

"Nothing in this Declaration may be interpreted as implying for any State, people, group or person any right to engage in any activity or to perform any act contrary to the Charter of the United Nations or construed as authorizing or encouraging any action which would dismember or impair, totally or in part, the territorial integrity or political unity of sovereign and independent States" (United Nations Declaration on the Rights of Indigenous Peoples, 2007, Art 46).

According to Agnieszka Szpak the emphasis on territorial integrity impliedly underscores the apprehension of nation states that recognition of the self-determination of the indigenous people can lead to demands for secession (Agnieszka Szpak, 2018, p. 181). However, as observed by several commentators the fear has no sound basis as the focus of most indigenous people are on making free and independent decisions pertaining to preserving their indigenous identity rather than creating a separate state (BAER, 2005, p. 255; Gunn, 2007, p. 68; OKAFOR, 2002, p. 41).

It should be noted that other than the Declaration, the Covenant on Civil and Political Rights also contain reference to the rights indigenous people. Art 27 of the Covenant contains special mandate of indigenous people in terms of protecting their culture, language, and ethnicity. This provision, however, stands in sharp contrast to Article 1 of the Covenant which contains a direct reference to self-determination of peoples. This apparent anomaly has often been used by nation states to undermine the right to self-determination of the indigenous people as reports on the rights of indigenous people are covered under Art 27 and not Art 1 . This effectively subverts any information on the state's efforts towards the self-determination of the indigenous people. 
To a certain extent the Human Rights Committee of the ICCPR was also complicit in interpreting that the indigenous people were protected under Art 27 rather than Art 1 (Koivurova, 2008, p. 6). However, from 1999 in accordance with Concluding Observations on the Periodic Report of Canada, the Committee requested the Canadian Government to base its report on the situation of indigenous people only under Art 27 but also under Article 1 of the ICCPR. Indeed, in its concluding observation the Committee observed:

"the Committee, while taking note of the concept of self-determination as applied by Canada to the aboriginal peoples, regrets that no explanation was given by the delegation concerning the elements that make up that concept, and urges the State party to report adequately on implementation of Article 1 of the Covenant in its next periodic report" (Concluding Observations of the Human Rights Committee on the Periodic Report of Canada, 1999, para.7).

The status of the Sami people in Norway and Finland and Sweden also constitutes a valid example in this context. In their reports to the Human Rights Committee in 2000 both Norway and Finland made a brief mention of the Sami people under Art 1 but a substantial portion of their rights were covered under Art 27 (Committee, Concluding observations on the sixth periodic report of Finland, 2013). Similarly, Sweden also reported about the Sami people under Art 27 on the pretext that the indigenous people are not people within the scope of GA Res. 1514 (XV) and GA Res. 1541 (XV) ((CCPR/C/SWE/2000/5, CCPR/C/74/L/SWE), 2002, Para 14). This position has, however, shifted over the years and in 2011 the Swedish Constitution recognised Sami as an indigenous people deserving protection under Art 1 of the Covenant.

As regards the implementation and interpreting the scope of Art 27, the Human Rights Committee of ICCPR have been very instrumental. The Human Rights Committee have interpreted the right as encompassing the "right of indigenous peoples to preservation of their livelihood, culture, language, traditional activities necessary for their survival and their customs" (Agnieszka Szpak, 2018, p. 32; Ivan Kitok v. Sweden, 1998; Lubicon Lake Band v. Canada, 1990; Aprrana Mahuika v New Zealand, 1993). In its General Comment, the Committee observed that

"With regard to the exercise of the cultural rights protected under article 27, the Committee observes that culture manifests itself in many forms, including a particular way of life associated with the use of land resources, especially in the case of indigenous peoples. That right may include such traditional activities as fishing or hunting and the right to live in reserves protected by law. The enjoyment of those rights may require positive legal measures of protection and measures to ensure the effective participation of members of minority communities in decisions which affect them". (Committee, CCPR/C/21/Rev.1/Add.5, 1994)

The juxtaposition between Article 1 and Article 27 has been further clarified in Apirana Mahuika et al v. New Zealand in which the Committee observed that "the provisions of article 1 may be relevant in the interpretation of other rights protected by the Covenant, in particular article 27". According to Małgosia Fitzmaurice one of main takeaway from the Apirana Mahuika et al. is that it gave clear indications that Art 1 of the ICCPR "may be relevant to the interpretation of other rights protected by the Covenant, in particular article 27" (Fitzmaurice, 2013, p. 354). 
Another important source of the rights of indigenous people is ILO Convention 169 of 1989. The ILO Convention does not expressly guarantee the right to self-determination. Its major emphasis is on autonomy of the indigenous people and their informed consent in matters concerning "legislative or administrative measures which may affect them directly" (ILO Art $6(1)(a)$ ). Among other things the Convention also emphasises on "people's participation at "all levels of decision making in elective institutions and administrative and other bodies responsible for policies and programmes which concern them. The Convention also aims to "establish means for the full development of these peoples' own institutions and initiatives, and in appropriate cases provide the resources necessary for this purpose". (ILO, Art 6 (1) (c)). The Convention also emphasises on the establishment of indigenous institutions and promote practices that facilitates in the participation of activities that are central to the interests of the indigenous people like their culture, religion, identity, language and land rights.

Strangely, while the ILO Convention 169 may not have a direct implication on selfdetermination it has found its uses in interpreting the content of reports submitted by states under Art 1 of the Economic Social and Cultural Covenant (ESCC). Notably the ESCC does not contain a separate mandate for indigenous people like the Civil and Political Covenant and all rights pertaining to the indigenous people are spread over different chapters of the Covenant. ${ }^{v}$ The diffusion of the rights makes it imperative under the ESCC for all reports to be submitted under Article 1 of the Covenant. While there is no doubt that the ILO Convention is a significant milestone in the field of rights of indigenous people, the lack of a direct guarantee of selfdetermination is conspicuous by its absence. State practice shows that reports on the selfdetermination of indigenous people are often interpreted in the light of the declarations in 169. ${ }^{\text {vi }}$ This in turn has enabled states to address the issue of the self-determination of the indigenous people under the ILO and not the Declaration on the Rights of Indigenous Peoples 2007.

\section{What does rights of indigenous persons mean in the context of self-determination?}

Summers argues that the right to self-determination of indigenous persons encompasses a "number of rights" that includes the following; Firstly, this right is indicative of political selfdetermination as it encompasses the right to participate in "political life of the state" (Summer, 2014, p. 316) Secondly, the right has implications for self-government. However, the stress on selfgovernment here is on autonomous political system of governance and not necessarily external sovereignty. vii In a sense, as Summers observe the focus on an autonomous political system flows from a respect of territorial integrity and to prevent unilateral declaration of independence (Summer, 2014, p. 317). viii Thirdly, the right also encompasses the right of the indigenous people to protect and develop their own culture and their "way of life". Fourthly, Summers observe that this right can also be associated with the indigenous people's right to "traditionally occupied territory (Summer, 2014, p. 317). Summers argue this right is indicative of the "right of peoples to dispose of their resources and protection of their subsistence". ix Fifthly, the right also includes the right to "dispose of their natural wealth and resources". Summers observe that this right connects to different rights in the ESCC including the right to manage their own resources. ${ }^{x}$

It should be noted that in the context of self-determination the right of indigenous person has often been seen to encompass the duty of states to consult the indigenous population 
specially in matters that affect their interests. ${ }^{x i}$ This is evidenced by state practice as well as the reports of the Human Rights Committee under both the Covenants. (Summer, 2014, p. 321) The focus on informed consent encompasses large-scale constructions like dam-building, timber and mining concessions and other larger projects. ${ }^{\text {xii }}$ While none of the instruments expressly contains provisions for informed, consent this requirement has been incorporated by a join reading of Article 27, Article 25 and Article 2 on non-discrimination of the Civil and Political Covenant (Summer, 2014, p. 317).

\section{Conclusion}

Except for some certainty in the context of colonisation, the concept of peoples lacks an acceptable meaning or definition in international law. As could be understood, most of the uncertainty follows from the reluctance of nation-states to recognise groups within its territory as units of self-determination. Scholars have attempted to give their own interpretation of the subject and presently it narrows down to a nationalist understanding of peoples and peoples under the remedial secession theory. Scholars have claimed that for self-determination to arise both in a nationalist and remedial secession scenario - it is a pre-condition that people have a nationalist connection with the territory. This is also the position taken by some states as regards the difference between settlers and peoples. This was seen in the context of Falkland war, where Argentina refused to recognise the secessionist claims of the people despite an overwhelming majority of the population supporting it. Outside the colonial context the self-determination is associated with two major groups - indigenous people and minorities. Unfortunately, unlike in the case of the colonial territories, international law has no definite policy on the self-determination of indigenous people or the minorities.

Even though international instruments endorse the right of indigenous people to certain rights, such instruments do not clarify whether the rights include the right of such groups to selfdetermination. But that is not even the main problem. The main problem revolves around the ambiguity surrounding the concept of indigenous persons and if they are peoples in the international law. Given that the peoples are the basic unit of self-determination, most nations refuse to accept the existence of indigenous people within their population, and even in cases where they do, they avoid using the term "people". Reports on indigenous people, which State's submits to the Human Rights Committee are based on Art 27 of the ICCPR (which does not refer to the self-determination of indigenous person) and Art 1 (which refers to the right of selfpeoples). In effect therefore, the effort of the nation states has been to present a picture of indigenous people who are not people within the meaning of self-determination. The same applies to the identification of minorities as peoples in the context of self-determination. Minorities are identified in association with a specific trait and their significance lies in terms of their association with their trait. Beyond the specific traits, however, there is no independent conception of minorities in international law. While the Declaration on the rights of the minorities recognise minorities independent of any qualification, it still does not expressly provide a framework for the self-determination of minorities. One solution that has been proposed is to read the right to self-determination by a cumulative interpretation of the majority of rights declared therein. They argue that the best solution is to provide for a minimum guarantee of self- 
determination by resorting to internal self-determination. Indeed, as the argument goes internal self-determination is compatible with both the need for preserving territorial integrity of the state as well as the self-determination of the peoples.

\section{References}

16 GAOR (1961). (1961). (A/C.3/SR.1103). Newyork: UN General Assembly.

Agnieszka Szpak, '. (2018). The Right of Indigenous Peoples to Self-Determination: International Law Perspective. Athenaeum Polskie Studia Politologiczne, 59, 178-204.

Ali, N. Y. (2014). For Better or worse? Force Marriage of Sovereignty and Self- Determination. Cornell International Law Journal, 47(2), 417-444.

Anaya, J. S. (1996). Indigenous Peoples in International Law (First ed.). Newyork: OUP.

Anaya, J. (2012). Report of the Special Rapporteur on the Rights of Indigenous People. UNGA. Retrieved June 24, 2021, from https://digitallibrary.un.org/record/782145

Aprrana Mahuika v New Zealand, U.N. Doc. CCPR/C/55/D/547/1993 (HUman rights Committee 1993).

Assembly, G. (2007). 107th Plenary meeting. UNGA. Retrieved June 18, 2021, from https://undocs.org/en/A/61/PV.107

Assembly, G. (UN). 107th plenary meeting. Retrieved June 24, 2021, from https://undocs.org/en/A/61/PV.107\&Lang=E

BAER, L.-A. (2005). The Rights of Indigenous Peoples - A Brief Introduction in the Context of the Sámi. International Journal on Minority and Group Rights, 12(2/3), 245-67.

Barten, U. (2015). Minorities, Minority Rights and Internal Self-Determination. Springer International Publishing.

Brando, N., \& Morals-Galvez, S. (2019). The Right to Secession: Remedial or Primary? Ethnopolitics, 18(2), 107-118.

Buchanan, A. (2017, August 15). Secession. (E. N. Zalta, Ed.) Retrieved 6 2021, 2017, from The Stanford Encyclopedia of Philosophy: https://plato.stanford.edu/archives/fall2017/entries/secession/>

Committee on Economic, S. a. (2012). Concluding observations of the Committee on the third periodic report of Ecuador as approved by the Committee atits forty-ninth session (14-30 November 2012). UN. Retrieved June 23, 2021, from https://undocs.org/E/C.12/ECU/CO/3

Committee, H. R. (1994). General Comment no.23 (1994, para.7). Retrieved June 13 , 2021, from https://www.refworld.org/docid/453883fc0.html

Committee, H. R. (2009). CONSIDERATION OF REPORTS SUBMITTED BY STATES PARTIES, Concluding observations of the Human Rights Committee. United Nations Publication. Retrieved JUne 23, 2021, from https://undocs.org/CCPR/C/RUS/CO/6

Committee, H. R. (2013). Concluding observations on the sixth periodic report of Finland. Retrieved from http://docstore.ohchr.org/SelfServices/FilesHandler.ashx?enc=6QkG1d\%2FPPRiCAqhKb7yhshDrA9 AyYXqXWEvDClgOPRGuojHipZZRfVkqVD1wqI2BGH85IGytBe\%2BMkZOI6fRILzRf\%2FBHg2eagz\%2B P6qmP0VHh6JKIgKCy7fFJ5nxEg4gyky 
Consideration of reports submitted by States parties under article 40 of the Covenant, Fifth periodic report of Sweden. (2002). UN. Retrieved from https://docstore.ohchr.org/SelfServices/FilesHandler.ashx?enc=6QkG1d\%2fPPRiCAqhKb7yhsm0BT KouDPNIMXWAuPwondHjddikldpxZ5hFgZIBHxcM34t5wnTkVzGOTJJA90BysqHxJcM67K\%2bPngLS I3d4Qto5ZyxqWpc\%2funr8H2V99qIE

Council, E. a. (2006). IMPLEMENTATION OF THE INTERNATIONAL COVENANTON ECONOMIC, SOCIAL AND CULTURAL RIGHTS. UN. Retrieved June 23, 2021, from file:///C:/Users/navins/Downloads/G0643931.pdf

Council, H. R. (2006). Report of the Human Rights Council. Newyork: UN. Retrieved JUne 18, 2021, from https://www2.ohchr.org/english/bodies/hrcouncil/docs/A.61.53.pdf

Davis, M. (1988). Indigenous Rights. In W. A. Macartney, Self-Determination in the Commonwealth. Aberdeen: Aberdeen Unviersity Press.

Fitzmaurice, M. (2013). The question of indigenous peoples' rights: A time for reappraisal? In D. French, Statehood and Self-Determination: Reconciling Tradition and Modernity in International Law (pp. 349-376). Cambridge Unviersity Press.

Gunn, B. L. (2007). rotecting Indigenous Peoples' Lands: Making Room for the Application of Indigenous Peoples' Laws within the Canadian Legal System. Indigenous Law Journal, 6(1), 31-69.

ILO. (n.d.). Indigenous and Tribal Peoples Convention, 1989 (No. 169). Retrieved JUne 16, 2021, from https://www.ilo.org/dyn/normlex/en/f?p=NORMLEXPUB:12100:0::NO::P12100_ILO_CODE:C169

Iorns, C. (1992). Indigenous Peoples and Self Determination: Challenging State Sovereignty. W. Res. J. Int'/ L, 199-348.

Ivan Kitok v. Sweden (The Human Rights Committee 1998).

Kingsbury, B. (1998). Indigenous Peoples" in International Law: A Constructivist Approach to the Asian Controversy'. The American Journal of International Law, 92(3), 414-457.

Kingsbury, B. (2008). "Indigenous Peoples" in International Law: A Constructivist Approach to the Asian Controversy. In C. Erni, The Concept of Indigenous People in Asia: A Resource Book (pp. 103-161). International Work Group for Indigenous Affairs (IWGIA), Asia Indigenous Peoples Pact Foundation.

Koivurova, T. (2008). From High Hopes to Disillusionment: Indigenous Peoples' Struggle to (Re)Gain Their Right to Self-Determination. International Journal on Minority and Group Rights, 15(1), 1-26.

Lubicon Lake Band v. Canada, U.N. Doc. Supp. No. 40 (A/45/40) at 1 (1990). (The Human rights Committee 1990).

Miller, D. (1998). Secession and the Principle of Nationality. In M. Moore, National Self-Determination and Secession. New york: OUP.

OKAFOR, O. C. (2002). Entitlement, Process, and Legitimacy in the Emergent International Law of Secession. International Journal on Minority and Group Rights, 9(1), 41-70.

Philpott, D. (1995). In Defense of Self-Determination. Ethics, 105(2), 352-385.

Quane, H. (2011). The UN Declaration on the Rights of Indigenous Peoples: New_Directions for SelfDetermination and Participatory Rights? In S. Allen, \& A. Xanthaki, Reflections on the UN Declaration on the Rights of Indigenous Peoples (pp. 259-287). Hart Publishing. 
Rights, C. (n.d.). REPORT ON THE FIFTY-FIFTH SESSION. UN. Retrieved June 15, 2021, from https://digitallibrary.un.org/record/267879/files/E_CN.4_1999_1_Add.1-EN.pdf?version=1

RIGHTS, C. O. (1993). Report of the Working Group on Indigenous Populations. UN. Retrieved June 16, 2021, from https://www.refworld.org/pdfid/3b00f49e4.pdf

Summer, J. (2014). Peoples and International Law (Second Edition ed.). Brill NIjhoff.

UN. (1945). UN Charter .

UN. (1960). Declaration on Granting of Independence to Colonial Countries and Peoples.

UN. (1966). ICCPR.

UN. (2008). Resource kit on Indigenous Poeples' Issues. Newyork: United Nations Publication. Retrieved June 23, 2021, from https://www.un.org/esa/socdev/unpfii/documents/resource_kit_indigenous_2008.pdf

United Nations Declaration on the Rights of Indigenous Peoples. (2007).

\section{Endnotes}

i See Article 1 of The International Covenant on Civil and Political Rights, 1966 and Article 1 of The international Covenant on Socio Economic and Cultural Rights, 1966. "All peoples have the right of selfdetermination, including the right to determine their political status and freely pursue their economic, social and cultural development."

ii GA. Res.1514

iii See for example Chile's definition of indigenous people Chile, 16 GAOR (1961), 3rd Cmttee., 1103rd mtg., (A/C.3/SR.1103) para. 21.

iv Summers, for example, argues that most nations resort to using monikers like 'small indigenous people', 'indigenous nationality' and 'indigenous population' whil referring to such groups. James Summers, Peoples and International Law (Second revised edition, Brill Nijhoff 2014). See the reports of Russia, Sixth Periodic Report 2007, CCPR/C/RUS/6, para. 5, Nepal Second Periodic Report 2006, E/C.12/NPL/2, para. 96., Ecuador, Third Periodic Report 2009, E/C.12/ECU/3, paras 16 and 19.

' See Committee on Economic, Social and Cultural Rights, General Comment No. 21 (43) 2009, paras. 3637; General Comment No. 20 (42) 2009, para. 18; General Comment No. 19 (39) 2008, para. 35; General Comment No. 17 (35) 2006, paras. 9, 18, 32, 45; General Comment No. 15 (29) 2002, para. 7 and 16; General Comment No. 14 (22) 2000, paras. 12 and 27; General Comment No. 13 (21) 1999, paras. 31 and 50; General Comment No. 12 (20) 1999, para. 13.

vi Brazil, Second Periodic Report 2004, CCPR/C/BRA/2004/2, para. 14; Norway, Fifth Periodic Report 2004, CCPR/C/NOR/2004/5, para. 238; Chile, Fifth Periodic Report 2006, CCPR/C/CHL/5, para. 51; Denmark, Fifth Periodic Report 2007, CCPR/C/DNK/5, para. 7; śEcuador, Fifth Periodic Report 2007, CCPR/C/ECU/5, para. 18; Peru, Fifth Periodic Report 2011, CCPR/C/PER/5, para. 16; Sweden, Sixth Periodic Report 2007, CCPR/C/SWE/6, paras 9-10; Nicaragua, E/C.12/2008/SR.29, para. 34; Paraguay, Second and Third Periodic Report 2006, E/C.12/PRY/3, para. 117 
vii Canada and the United States, have also stressed this did not imply sovereignty in the international legal sense.211Canada, CCPR/C/SR.1737 (1999) para. 7; US, CCPR/C/SR.1405 (1995) para. 67; United States, Initial Report 1994, CCPR/C/81/Add.4, paras. 26-76.

viii Canada, CCPR/C/SR.1737 (1999) para.5; CCPR/C/SR.1738 (1999) para. 3; Mexico, Fifth

Periodic Report 2008, CCPR/C/MEX/5, paras. 36-37.

ix This right may connect to Article 1, especially in paragraph 2 on the right of peoples to dispose of their resources and protection of their subsistence, but it can also be seen as an aspect of Article 27. Also see, Peru, Fifth Periodic Report 2011, CCPR/C/PER/5, para. 11; Bolivia, Third Periodic Report 2011, CCPR/C/BOL/3, paras. 30-31; Guatemala, Third Periodic Report 2009, CCPR/C/GTM/3, para. 11; Ecuador, Third Periodic Report 2009, E/C.12/ECU/3, para. 30; Brazil, Second Periodic Report 2007, E/C.12/BRA/2, para. 81.icle 1, especially in paragraph 2 on the right of peoples to dispose of their resources and protection of their subsistence, but it can also be seen as an aspect of Article 27.

x See Committee on Economic, Social and Cultural Rights, General Comment No. 15 (29) (2002) para. 7 and 16; General Comment No. 12 (20) (1999) para. 13.According to summers The right to the resources to enable indigenous populations to pursue their way of life has also featured prominently in interpretations of indigenous rights under Article 27, with the Human Rights Committee recommending positive obligations for states to legislate in this area.

xi Concluding Observations of the Committee on Economic, Social and Cultural Rights, Nicaragua 2008, E/C.12/NIC/CO/4, para. 11.

xii 229 Concluding Observations of the Committee on Economic, Social and Cultural

Rights, Mexico 2006, E/C.12/MEX/CO/4, para. 28. List of Issues, Ecuador 2011, E/C.12/ECU/Q/3, para. 2.

230 Concluding Observations of the Committee on Economic, Social and Cultural

Rights, Brazil 2003, E/C.12/1/Add.87, para. 58. 